THE WILD GOD OF THE WORLD 



\section{The Wild God of the World}

AN ANTHOLOGY OF

\section{Robinson Jeffers}

Selected, with an Introduction, by

ALBERT GELPI

Stanford University Press

STANFORD, CALIFORNIA 2003 
All rights reserved. (C) 2003 by the Board of Trustees of the Leland Stanford Junior University "Animals" (C) 1925, 1929 and renewed 1953, 1957 by Robinson Jeffers; "Apology for Bad Dreams" (C) 1925 and renewed 1953 by Robinson Jeffers; "The Beauty of Things" (C) 1925, 1929 and renewed 1953, 1957 by Robinson Jeffers; "The Bed by the Window" (C) 1925, 1929 and renewed 1953, 1957 by Robinson Jeffers; "Birds and Fishes" (C) 1963 by Stuben Glass; "The Bloody Sire" (C) 1940 and renewed 1968 by Donnan Jeffers and Garth Jeffers; "Boats in a Fog" (C) 1925 and renewed 1953 by Robinson Jeffers; "Carmel Point" (C) 1954 by Robinson Jeffers; "Cassandra" (C) 1925,1929 and renewed 1953, 1957 by Robinson Jeffers; "Continents End" (C) 1924 and renewed 1952 by Robinson Jeffers; "The Deer Lay Down Their Bones" (C) 1925, 1929 and renewed 1953, 1957 by Robinson Jeffers; "De Rerum Virtute" (C) 1954 by Robinson Jeffers; "The Eye" (C) 1925, 1929 and renewed 1953, 1957 by Robinson Jeffers; "For Una" (C) 1925, 1929 and renewed 1953, 1957 by Robinson Jeffers; "Hurt Hawks" (C) 1928 and renewed 1956 by Robinson Jeffers; "Love the Wild Swan" (C) 1935 and renewed 1963 by Donnan Jeffers and Garth Jeffers; "Original Sin" (C) 1925, 1929 and renewed 1953, 1957 by Robinson Jeffers; "The Purse Seine" (C) 1938 and renewed 1966 by Donnan Jeffers and Garth Jeffers; "Return" (C) 1935 and renewed 1963 by Donnan Jeffers and Garth Jeffers; "Rock and Hawk" (C) 1925, 1929 and renewed 1953, 1957 by Robinson Jeffers; "Shine, Perishing Republic" (C) 1934 and renewed 1962 by Donnan Jeffers and Garth Jeffers; "Tor House” (C) 1925, 1929 and renewed 1953, 1957 by Robinson Jeffers; "To the Stone Cutters" (C) 1924 and renewed 1952 by Robinson Jeffers; "Vulture" (C) 1963 by Garth Jeffers and Donnan Jeffers, from The Selected Poems of Robinson Jeffers by Robinson Jeffers, (C) 1925, 1929, and renewed 1953, 1957 by Robinson Jeffers. Used by permission of Random House, Inc. All other poems (C) Jeffers Literary Properties. Reprinted by permission.

Printed in the United States of America on acid-free, archival-quality paper

Library of Congress Cataloging-in-Publication Data

Jeffers, Robinson, 1887-1962.

The wild god of the world : an anthology of Robinson Jeffers / selected, with an introduction, by Albert Gelpi.

p. $\mathrm{cm}$.

Includes index.

ISBN o-8047-4591-9 (alk. paper) — ISBN o-8047-4592-7 (pbk. : alk. paper)

I. Gelpi, Albert. II. Title.

PS3519.E27 A6 2003

$811^{\prime} .52-\mathrm{dc} 21$

2002153166

Designed and typeset by Jeff Clark at Wilsted \& Taylor Publishing Services in 11.5/13 Centaur, following Adrian Wilson's original design for The Collected Poetry of Robinson Jeffers

Original Printing 2003

Last figure below indicates year of this printing:

$\begin{array}{lllllllll}\text { II } & 10 & 09 & 08 & 07 & 06 & 05 & 04 & 03\end{array}$ 